\title{
PENERAPAN SISTEM DAN PROSEDUR AKUNTANSI PENGELOLAAN DANA DESA DI DESA TINCEP KECAMATAN SONDER KABUPATEN MINAHASA
}

\author{
Kenny Larony Tangkaroro ${ }^{1}$, Ventje Ilat $^{2}$, Heince Wokas ${ }^{3}$ \\ 1,2,3 Jurusan Akuntansi, Fakultas Ekonomi dan Bisnis, Universitas Sam Ratulangi, Jl. Kampus Bahu, Manado, \\ 95115, Indonesia
}

Email : tangkarorokenny@gmail.com

\begin{abstract}
The purpose of this study is to analyze the problems experienced by villages related to the management of village funds and also to analyze the Application of Accounting System for Village Fund Management which includes Cash Receipts, Cash Expenditures, Fixed Assets, and Taxes. This research was conducted in Tincep Village, Sonder Sub District, Minahasa District. This research uses descriptive qualitative method. The results show that the management of village funds in Tincep Village is in accordance with Permendagri No.113 of 2014 and the priority of the use of village funds in Tincep Village is also appropriate based on PermenDesaPDTT No. 22 of 2016, The application of accounting system in Tincep village is in accordance with the legislation, but if viewed from the side of administrative supervision is still not fully in accordance with the provisions, especially in the process of cash expenditures that have not been accountable and often not appropriate procedures. Therefore the author suggests that the need for a computerized accounting system so that later every accounting process can be done quickly and the output of financial statements will also be more reliable than the reporting manually, also in the future it is expected that management related to village fund can be done more accountable and transparent.
\end{abstract}

Keywords : Management of village finances, accounting information system, village fund

\section{PENDAHULUAN}

Pedesaan merupakan bagian integral dari Negara Republik Indonesia. Membangun desa berarti membangun sebagian besar penduduk Indonesia, Eko (2014: 2) dikutip dalam Ismail Muhammad (2016) Menyatakan bahwa Negara berdiri mengikuti perkembangan desa atau tut wuri handayani. Hal ini mudah dimengerti karena lebih dari delapan puluh persen penduduk Indonesia tersebar di desa-desa seluruh Indonesia. Hoesada (2016: 231) menyatakan bahwa Pembangunan sarana prasarana desa dan dusun pada tahun-tahun yang akan datang akan meningkat secara signifikan, aparat desa akan mendapat gaji dari Negara. Brodjonegoro (2014) dikutip dalam Ismail Muhammad (2016) menyatakan bahwa Desa akan segera mendapatkan dana miliaran rupiah, Alokasi Anggaran Pendapatan dan Belanja Negara untuk desa akan selalu meningkat dari tahun ke tahun.

Berdasarkan Permendagri No. 113 Tahun 2014 Pasal 1 ayat (9), "Dana Desa adalah dana yang bersumber dari APBN yang diperuntukan bagi desa yang di transfer melalui APBD Kab/Kota yang digunakan untuk membiayai penyelenggaraan pemerintahan, pelaksanaan pembangunan, pembinaan kemasyarakatan, dan pemberdayaan masyarakat". (BPKP 2015: 2) menyatakan bahwa dalam hal pengelolaan dana desa, akan ada risiko terjadinya kesalahan baik bersifat administratif maupun substantif yang dapat mengakibatkan terjadinya permasalahan hukum mengingat belum memadainya kompetensi kepala desa dan aparat desa dalam hal penatausahaan, pelaporan, dan pertanggungjawaban keuangan desa. Hal itu terjadi karena pemerintahan desa yang akan mendapatkan pendanaan program dan kegiatan dari berbagai sumber (APBN dan APBD Provinsi/Kabupaten) mengandung konsekuensi harus mampu mengelola secara transparan, akuntabel, dan bebas dari penyalahgunaan. 
Maka dari itu Sistem informasi akuntansi sangatlah diperlukan dalam menunjang pemerintah Desa Tincep terutama dalam menjalankan pengelolaan keuangan yang baik dan juga sesuai dengan prosedur yang semestinya agar nantinya dapat mempermudah dalam hal pelaporan dan pertanggungjawaban kepada pemerintah kabupaten dalam hal ini yang berkaitan dengan dana desa. Berdasarkan latar belakang masalah yang telah diuraikan, maka penulis merumuskan masalah yang akan di bahas yaitu, Bagaimana Penerapan Sistem dan prosedur Akuntansi Pengelolaan Dana Desa di Desa Tincep? Tujuan yang ingin di capai dalam penelitian ini adalah untuk mengetahui Penerapan Sistem Akuntansi dan Prosedur Pengelolaan Dana Desa di Desa Tincep Kecamatan Sonder Kabupaten Minahasa.

\section{TINJAUAN PUSTAKA}

\subsection{Pengertian Akuntansi}

American Accounting Association (AAA) menyatakan bahwa Akuntansi adalah proses identifikasi, pengukuran dan pelaporan informasi ekonomi untuk memungkinkan adanya penilaian dan keputusan yang jelas serta tegas bagi pengguna informasi tersebut. Selanjutnya Sujarweni (2015: 18) menjelaskan bahwa akuntansi pemerintahan adalah akuntansi yang bersangkutan dengan bidang keuangan negara, dari anggaran sampai dengan pelaksanaan dan pelaporannya, termasuk segala pengaruh yang ditimbulkannya.

\subsection{Pengertian Sistem}

Sistem merupakan kumpulan elemen yang saling bekerja sama untuk mencapai tujuan tertentu. Susanto Azhar (2013: 22) dalam bukunya yang berjudul Sistem Informasi Akuntansi, menjelaskan bahwa Sistem adalah kumpulan/group dari sub sistem/bagian/komponen apapun baik phisik ataupun non phisik yang saling berhubungan satu sama lain dan bekerja sama secara harmonis untuk mencapai satu tujuan tertentu. Sistem ini mempunyai jaringan dan prosedur yang disusun dalam rangkaian secara menyeluruh, untuk melaksanakan berbagai kegiatan atau fungsi pokok dalam suatu badan usaha.

\subsection{Pengertian Sistem Akuntansi}

Mulyadi $(2016$; 3 ) menjelaskan bahwa sistem akuntansi adalah organisasi formulir, catatan, dan laporan yang di koordinasikan sedemikian rupa untuk menyediakan informasi keuangan yang dibutuhkan oleh manajemen guna memudahkan pengelolaan perusahaan.

Sistem akuntansi yang dirancang dan dijalankan secara baik akan menjamin dilakukannya prinsip stewardship dan accountability dengan baik pula. Pemerintah atau unit kerja pemerintah perlu memiliki sistem akuntansi yang tidak hanya berfungsi sebagai alat pengendalian transaksi keuangan, akan tetapi sistem akuntansi tersebut hendaknya mendukung pencapaian tujuan organisasi.

\subsection{Fungsi dan Tujuan Sistem Informasi Akuntansi}

Bodnart (2012: 11) dikutip dalam Tenda Stefy (2015) menyatakan bahwa Fungsi sistem informasi akuntansi yaitu bertanggungjawab untuk memproses dan mengolah data dan bertujuan untuk memperbaiki kualitas informasi, memperbaiki pengendalian internal, dan meminimalkan biaya berlebihan.

\subsection{Dana Desa}

Peraturan Pemerintah No. 60 Tahun 2014 tentang Dana Desa yang bersumber dari APBN menjelaskan bahwa Dana Desa adalah dana yang bersumber dari Anggaran Pendapatan dan Belanja Negara yang diperuntukkan bagi Desa yang ditransfer melalui Anggaran Pendapatan dan Belanja Daerah Kabupaten/Kota dan digunakan untuk membiayai penyelenggaraan pemerintahan, pelaksanaan pembangunan, pembinaan kemasyarakatan, dan pemberdayaan masyarakat. 


\subsection{Pengelolaan Keuangan Desa}

Dalam Permendagri No. 113 tahun 2014, dikatakan bahwa Pengelolaan Keuangan Desa adalah keseluruhan kegiatan yang meliputi perencanaan, pelaksanaan, penatausahaan dan pertanggungjawaban keuangan desa. Namun dalam penelitian ini yang lebih difokuskan adalah pada proses pelaksanaan dan penatausahaan dana desa.

\section{Pelaksanaan}

Dalam pelaksanaan anggaran desa yang sudah ditetapkan sebelumnya timbul transaksi penerimaan dan pengeluaran desa. Semua penerimaan dan pengeluaran desa dalam rangka pelaksanaan kewenangan desa dilaksanakan melalui rekening kas desa. Jika desa yang belum memiliki pelayanan perbankan di wilayahnya maka pengaturannya ditetapkan oleh Pemerintah Kabupaten/Kota. Semua penerimaan dan pengeluaran desa harus didukung oleh bukti yang lengkap dan sah. Beberapa aturan dalam pelaksanaan pengelolaan keuangan desa sebagai berikut.

a. Pemerintah desa dilarang melakukan pungutan sebagai penerimaan desa selain yang ditetapkan dalam peraturan desa;

b. Bendahara dapat menyimpan uang Kas Desa pada jumlah tertentu dalam rangka memenuhi kebutuhan operasional pemerintah desa;

c. Pengaturan jumlah uang dalam kas desa ditetapkan dalam Peraturan Bupati/Walikota;

d. Pengeluaran desa yang mengakibatkan beban pada APBDesa tidak dapat dilakukan sebelum Rancangan Peraturan Desa tentang APBDesa ditetapkan menjadi Peraturan Desa;

e. Pengeluaran desa tidak termasuk untuk belanja pegawai yang bersifat mengikat dan operasional perkantoran yang ditetapkan dalam peraturan kepala desa;

f. Penggunaan biaya tak terduga terlebih dulu harus dibuat Rincian Anggaran Biaya yang telah disahkan oleh Kepala Desa;

g. Pelaksana kegiatan yang mengajukan pendanaan untuk melaksanakan kegiatan harus disertai dengan dokumen antara lain Rencana Anggaran Biaya;

h. Rencana Anggaran Biaya diverifikasi oleh Sekretaris Desa dan disahkan oleh Kepala Desa;

i. Pelaksana kegiatan bertanggungjawab terhadap tindakan pengeluaran yang menyebabkan atas beban anggaran belanja kegiatan dengan mempergunakan buku pembantu kas kegiatan sebagai pertanggungjawaban.

\section{Penatausahaan}

Kepala desa dalam melaksanakan penatausahaan keuangan desa harus menetapkan bendahara desa. Penetapan bendahara desa harus dilakukan sebelum dimulainya tahun anggaran bersangkutan dan berdasarkan keputusan kepala desa. Ardi Hamzah dikutip oleh Sujarweni (2015) menyatakan bahwa Bendahara desa adalah perangkat desa yang ditunjuk oleh kepala desa dalam rangka pelaksanaan APBDesa. Bendahara desa wajib mempertanggungjawabkan uang melalui laporan pertanggungjawaban. Laporan pertanggungjawaban disampaikan setiap bulan kepada Kepala Desa dan paling lambat tanggal 10 bulan berikutnya. Dalam Permendagri No. 113 tahun 2014 laporan pertanggungjawaban yang wajib dibuat oleh bendahara desa adalah sebagai berikut.

a. Buku Kas Umum

Buku kas umum digunakan untuk mencatat berbagai aktivitas yang menyangkut penerimaan dan pengeluaran kas, baik secara tunai maupun kredit, digunakan juga untuk mencatat mutasi perbankan atau kesalahan dalam pembukuan. Buku kas umum dapat dikatakan sebagai sumber dokumen transaksi.

b. Buku Pembantu Pajak

Buku pajak digunakan untuk membantu buku kas umum, dalam rangka penerimaan dan pengeluaran yang berhubungan dengan pajak.

c. Buku Bank 
Buku bank digunakan untuk membantu buku kas umum, dalam rangka penerimaan dan pengeluaran yang berhubungan dengan uang bank.

\subsection{Penelitian Terdahulu}

Muhammad Ismail (2016), dengan judul : Sistem Akuntansi Pengelolaan Dana Desa. Hasil penelitian menunjukkan bahwa permasalahan utama yang timbul adalah rendahnya pengetahuan dari kepala desa terkait pengelolaan keuangan desa berdasarkan Permendagri No. 113/2014. Terdapat persamaan dari penelitian tersebut yaitu, melakukan penelitian mengenai pengelolaan keuangan desa yang berdasarkan peraturan.

Nunuk Riyani (2016), dengan judul : Analisis Pengelolaan Dana Desa (Studi Kasus Di Desa Singopuran Kecamatan Kartasura Kabupaten Sukoharjo Tahun 2016). Hasil penelitian ini menunjukan bahwa Analisis Dana Desa di Desa Singopuran Kecamatan Kartasura Kabupaten Sukoharjo sudah tersampaikan untuk pembangunan dengan baik sesuai dengan rencana namun masih ada evaluasi yang perlu diperbaiki. Terdapat persamaan dari penelitian tersebut yaitu mencari tahu apakan pengelolaan Dana Desa sudah sesuai dengan peraturan yang ada.

\section{METODE PENELITIAN}

\subsection{Jenis Penelitian}

Untuk melihat sejauh mana implementasi program dana desa khususnya dalam pelaksanaan dan penatausahaanya oleh Pemerintah Desa, juga melihat bagaimana upaya Pemerintah Desa dalam mengoptimalkan pemanfaatan dana desa, maka digunakan metode penelitian kualitatif dengan melakukan studi kasus.

\subsection{Tempat dan Waktu Penelitian}

Peneliti mengambil tempat penelitian di Desa Tincep Kecamatan Sonder Kabupaten Minahasa. Waktu penelitian yaitu bulan Juni sampai September 2017

\subsection{Prosedur Penelitian :}

1. Menentukan Judul Penelitian

2. Menghubungi Pemerintah Desa untuk memohon izin melakukan Penelitian

3. Melakukan Observasi awal terhadap objek penelitian

4. Melakukan wawancara dengan Perangkat Desa di Desa Tincep dalam hal ini Sekretaris dan Bendahara Desa

5. Membuat Dokumentasi dan mengumpulkan data

\subsection{Metode Pengumpulan Data}

\subsubsection{Jenis Data}

Dalam penelitian ini digunakan data jenis kualitatif, data kualitatif adalah data yang disajikan secara deskriptif atau dalam bentuk uraian. Muntahanah dalam Dewanti (2016) menyatakan bahwa penelitian kualitatif yaitu penelitian yang digunakan dalam rangka mendapatkan data deskritif berupa kata- kata tertulis dari orang atau sampel yang digunakan sebagai responden penelitian.

\subsubsection{Sumber Data}

Berdasarkan sumbernya, data penelitian dapat dikelmpokkan dalam dua jenis yaitu, data primer dan data sekunder.

a. Indrawan dan Yaniawati (2014: 10) menyatakan bahwa Data Primer adalah sumber data yang langsung memberikan data kepada pengumpul data. Sumber primer ini berupa catatan hasil wawancara yang diperoleh melalui wawancara serta observasi lapangan yang dilakukan oleh peneliti, Dalam penelitian ini data primer di peroleh dari hasil wawancara langsung dengan perangkat desa di Desa Tincep.

b. Data Sekunder : data yang diperoleh dari dokumen-dokumen yang berkaitan dengan pembahasan, literature, serta sumber lainnya yang berkaitan dengan objek penelitian. 


\subsection{Teknik Pengumpulan Data}

Teknik pengumpulan data yang digunakan yaitu dengan teknik wawancara dan dokumentasi yaitu peneliti melakukan wawancara langsung dengan informan yang berkaitan langsung dengan Sistem Akuntansi yang diterapkan di desa apakah sudah sesuai dengan ketentuan perundang-undangan yang berlaku, dan juga mengenai pengelolaan dana desa apakah sudah dikelola dengan semestinya. dan mengumpulkan langsung dokumen-dokumen yang berkaitan dengan kegiatan tersebut.

\subsection{Metode Analisis}

Dalam penulisan penelitian ini peneliti menggunakan metode analisis deskriptif. Yaitu suatu metode pembahasan permasalahan yang sifatnya menggunakan, menggambarkan, dan membandingkan satu data atau keadaan serta melukiskan dan menerangkan suatu keadaan sedemikian rupa sehingga dapat di tarik kesimpulan.

\section{HASIL ANALISIS DAN PEMBAHASAN}

\subsection{Hasil Analisis}

\subsubsection{Akuntansi Penerimaan Kas}

Penerimaan Desa adalah uang yang berasal dari seluruh pendapatan desa yang masuk ke APB Desa melalui Rekening Kas Desa atau telah diterima oleh Bendahara Desa.

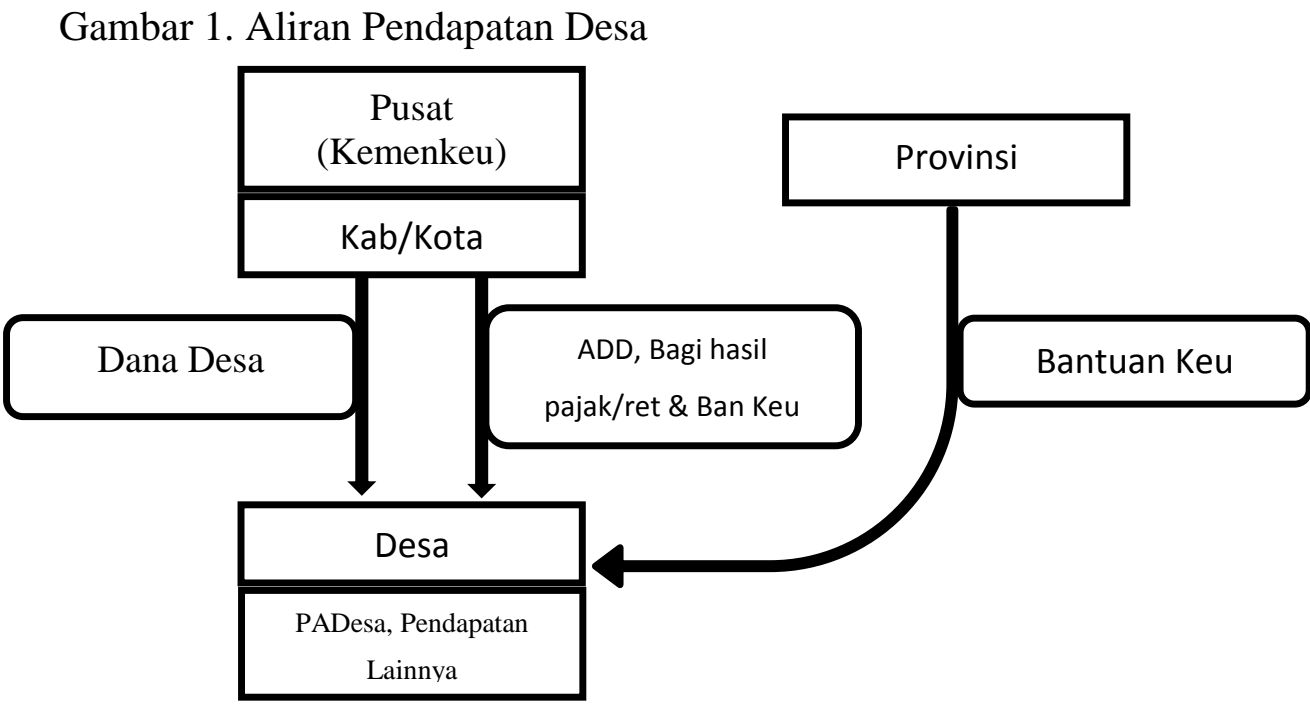

Sumber : Diolah dari peraturan tentang Desa

Di dalam penelitian ini yang menyangkut dengan Dana Desa yang berada dalam kelompok pendapatan transfer, Menurut Lukman Hakim (2016: 9) Dana Desa ditransfer melalui APBD kabupaten/kota untuk selanjutnya ditransfer ke APB Desa. Penyaluran Dana Desa dilakukan dengan cara pemindahbukuan dari RKUN ke RKUD, selanjutnya dari kabupaten/kota disalurkan ke desa dilakukan dengan cara pemindah bukuan dari RKUD ke Rekening Kas Desa. Berikut skema penyaluran Dana Desa yang dilakukan secara bertahap : Penyaluran tahap I : yaitu pada bulan maret sebesar 60\%, 7 hari kerja setelah diterima dari RKUN dengan syarat sebagai berikut :

1. Perdes APB Desa

2. Lapporan realisasi penggunaan DD pada tahun anggaran sebelumnya

Penyaluran tahap II : yaitu pada bulan Agustus sebesar 40\% , 7 hari kerja setelah diterima dari RKUN dengan syarat sebagai berikut :

1. Laporan penggunaan DD tahap I

2. Paling kurang $50 \%$ DD tahap I telah digunakan 


\subsubsection{Akuntansi Pengeluaran Kas}

Akuntansi Pengeluaran Kas merupakan sistem yang digunakan untuk mencatat seluruh transaksi pengeluaran kas. Penatausahan pengeluaran kas merupakan serangkaian proses kegiatan menerima, menyimpan, menyetor, membayar, menyerahkan, dan mempertanggungjawabkan pengeluaran uang yang berada dalam pengelolaan keuangan desa.

Berdasarkan Peraturan Pemerintah Desa Tincep Nomor 2 Tahun 2014 tentang RPJM

Desa Tincep pada Tahun 2016 prioritas masalah yang harus diselesaikan yang berkaitan dengan Penggunaan Dana Desa meliputi masalah di bidang Penyelenggaraan Pemerintahan Desa, Pelaksanaan Pembangunan Desa, Pembinaan Kemasyarakatan dan Pemberdayaan Masyarakat secara rinci permasalahan tersebut adalah sebagai berikut :

1. Masalah Pelaksanaan Pembangunan Desa ; yaitu sebagian besar masyarakat Desa Tincep menggantungkan hidupnya pada hasil pertanian, masyarakat susah untuk mengembangkan hasil pertanian disebabkan karena kesulitan untuk mengangkut hasil pertanian terutama di musim hujan karena akses jalan di perkebunan (2 lokasi) masih dalam tahap penyelesaian.

2. Masalah Pembinaan Kemasyarakatan ; yaitu pengadaan prasarana pos kamling Desa

3. Masalah Pemberdayaan Masyarakat ; yaitu perlu adanya pelatihan peningkatan kapasitas aparat desa dalam pengelolaan keuangan Desa (administrasi dana Desa), dan perencanaan pembangunan desa.

\subsubsection{Asset Tetap}

Pengertian Asset Desa yaitu adalah barang milik desa yang berasal dari kekayaan asli milik desa, dibeli atau diperoleh atas beban Anggaran Pendapatan dan Belanja Desa (APB Desa) atau perolehan hak lainnya yang sah.

Selanjutnya Asset Desa yang merupakan bagian dari Kekayaan Asli Desa dapat berupa Tanah kas desa, tanah ulayat, pasar desa, pasar hewan, tambatan perahu, bangunan desa, pelelangan ikan, pelelangan hasil pertanian, hutan milik desa, mata air milik desa, pemandian umum, dan asset lainnya milik desa.

Asset Desa lainnya yaitu :

1. Kekayaan desa yang diperoleh dari hibah dan sumbangan atau sejenisnya

2. Kekayaan desa yang dibeli atau diperoleh atas beban APBN, APBD, serta APBDesa

3. Kekayaan desa yang diperoleh sebagai pelaksanaan dari perjanjian/kontrak dan lainlain sesuai dengan ketentuan perundang-undangan.

4. Kekayaan desa yang berasal dari perolehan lainnya yang sah

5. Hasil kerjasama desa

Ketentuan Umum Pengelolaan Asset Desa :

1) Asset desa yang berupa tanah disertifikatkan atas nama pemerintah desa

2) Asset desa berupa bangunan harus dilengkapi dengan bukti status kepemilikan dan ditatausahakan dengan tertib

3) Asset desa dapat diasuransikan sesuai kemampuan keuangan desa dan dilaksanakan sesuai ketentuan peraturan perundang-undangan.

4) Asset desa dilarang untuk diserahkan kepada pihak lain sebagai pembayaran atas tagihan kepada pemerintah desa

5) Asset desa dilarang digadaikan atau dijadikan jaminan untuk mendapatkan pinjaman. 
Berikut daftar Asset Desa Tincep :

Tabel 1. Daftar Asset Desa Tincep

\begin{tabular}{|c|c|c|c|}
\hline No & Asset Desa & Jumlah & Keterangan \\
\hline 1. & Balai Pertemuan & 1 & Baik \\
\hline 2. & Tanah/Lapangan Sepak bola & 1 & Baik \\
\hline 3. & Air Bersih & & Baik \\
\hline 4. & Mesin Pencampur (Mixer) bahan banguan & 1 & Baik \\
\hline 5. & Mesin Cetak Hollobrik & 1 & Baik \\
\hline 6. & Mobil Ambulance & 1 & Baik \\
\hline
\end{tabular}

Sumber : Data Olahan

\subsubsection{Pajak}

Menurut Undang-undang Nomor 28 Tahun 2007, Pajak adalah kontribusi wajib kepada Negara yang bersifat memaksa berdasarkan undang-undang dan dipergunakan untuk kepentingan Negara bagi sebesar-besarnya kemakmuran rakyat . Di dalam penelitian ini yaitu yang berkaitan dengan penggunaan dana desa, Objek pajak yang di kenakan adalah Pajak Penghasilan dan Pajak Pertambahan Nilai.

Gambar 2. Objek Pajak penggunaan Dana Desa

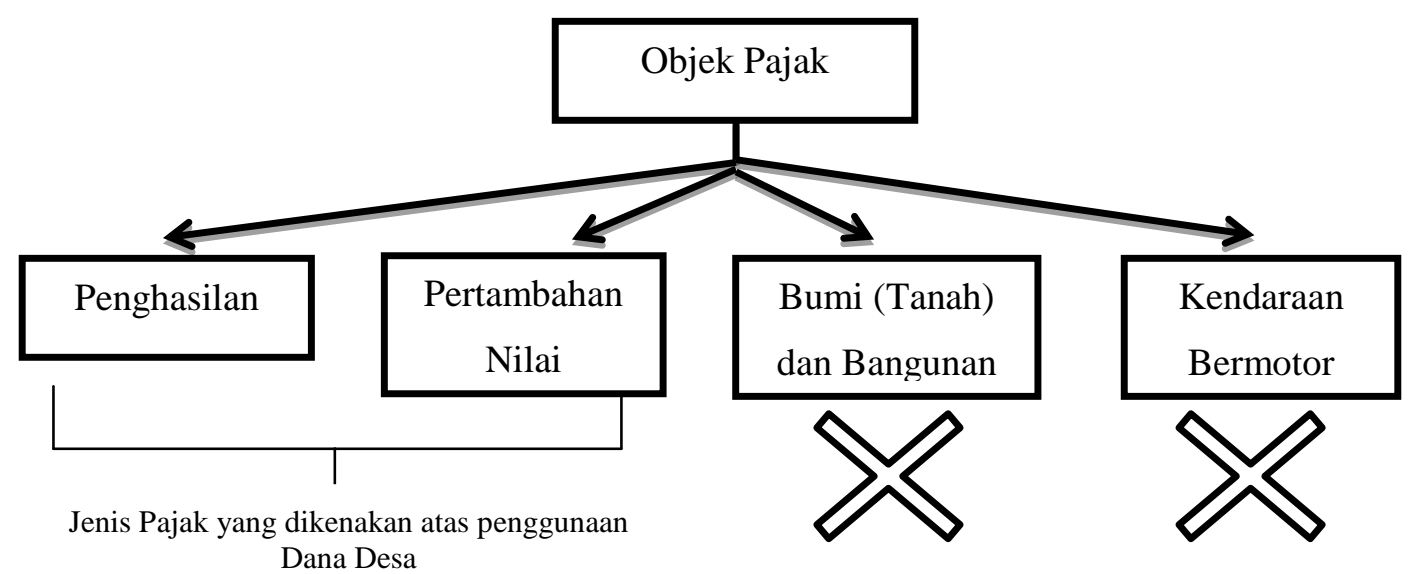

Sumber : Data Olahan

Di dalam penggunaan Dana Desa Bendahara desa berperan sebagai Wajib Pungut, Sesuai dengan yang tertuang dalam Permendagri No.113 Tahun 2014 yang mengatakan :

"Bendahara Desa sebagai wajib pungut pajak penghasilan dan pajak lainnya, wajib menyetorkan seluruh penerimaan potongan pajak yang dipungutnya ke rekening kas Negara sesuai dengan ketentuan"

Jenis - jenis pajak terkait Penggunaan Dana Desa, yaitu :

1. PPh Pasal 21 ;

Pajak yang dipotong atas pembayaran berupa gaji, upah, honorarium, dan pembayaran lain yang di terima oleh orang pribadi.

2. PPh Pasal 22 ;

Pajak yang dipungut dari Pengusaha/Toko atas pembelian barang dengan nilai pembelian diatas Rp. 2.000.000,- tidak terpecah-pecah.

3. PPh Pasal 23 ; 
Pajak yang dipotong dari penghasilan yang diterima rekanan atas sewa (tidak termasuk sewa tanah dan atau bangunan), serta imbalan jasa manajemen, jasa teknik, jasa konsultan, dan jasa lainnya.

4. PPh Pasal 4 ayat (2);

Pajak yang dipotong atas pembayaran :

a. Pengalihan hak atas tanah dan atau bangunan (Tarif 5\%)

b. Persewaan tanah dan atau bangunan (Tarif 10\%)

c. Jasa konstruksi (Tarif 2\%)

5. Pajak Pertambahan Nilai (PPN) ;

Pemungutan atas pembelian barang/jasa kena pajak yang jumlahnya di atas Rp. 1.000.000,- tidak merupakan pembayaran yang terpecah-pecah.

\subsection{Pembahasan \\ Pengelolaan Dana Desa}

Berdasarkan pengamatan dan wawancara yang di lakukan oleh penulis dengan perangkat desa Tincep beserta dengan dokumen yang di peroleh dari penelitian ini, penulis menilai bahwa Prosedur Pengelolaan Dana Desa di Desa Tincep ini sudah sesuai dengan semestinya yang dapat di lihat dari hal-hal berikut.

1. Terdapat pembagian tugas dan wewenang yang jelas dalam Pengelolaan Dana Desa dari setiap komponen perangkat desa.

2. Prioritas Penggunaan Dana Desa yaitu di Bidang Pembangunan dan Pemberdayaan, sesuai dengan Pasal 4 ayat (1) Peraturan Menteri Desa, Pembangunan Daerah Tertinggal, Dan Transmigrasi Republik Indonesia Nomor 22 Tahun 2016

3. Prioritas Pembangunan Desa yaitu untuk pembuatan jalan perkebunan (pembuatan jalan lapis beton) yang di mana sebagian besar masyarakat Desa Tincep berprofesi sebagai petani dan untuk menunjang kelancaran kegiatan pertanian, Sesuai dengan Pasal 3 bagian (b) Peraturan Menteri Desa, Pembangunan Daerah Tertinggal, Dan Transmigrasi Republik Indonesia Nomor 22 Tahun 2016.

\section{Penerapan Sistem dan Prosedur Akuntansi}

1. Penerimaan Kas

Menurut Penelitian yang dilakukan, Sistem Penerimaan Kas di Desa Tincep sudah sesuai dengan tahapan yang semestinya, dimana bendahara desa menerima pendapatan dan dicatat dalam buku bank. Namun sering juga terdapat masalah namun bukan semata-mata disebabkan oleh internal desa, melainkan juga disebabkan permasalahan makro baik ditingkat Kecamatan, Kabupaten, Provinsi maupun Pemerintah Pusat, misalnya seperti keterlambatan dalam pencairan dana.

2. Pengeluaran Kas

Menurut Penelitian yang dilakukan, Sistem Pengeluaran Kas di Desa Tincep secara pencatatan sudah sesuai dengan semestinya, namun masih ada hal yang harus perlu di perhatikan yaitu masih terdapat dua pemegang keuangan yang dalam hal ini Hukum tua dan Bendahara desa, yang dimana seharusnya Bendahara desa yang membidangi urusan administrasi keuangan untuk menatausahakan keuangan desa (Pasal 1 ayat (16) Permendagri No. 113 Tahun 2014), sehingga dengan demikian seringkali ada pengeluaran yang tidak langsung diketahui oleh bendahara, dan mengakibatkan hambatan dalam proses pembuatan laporan, dimana prosedur yang seharusnya yaitu dimulai dari pelaksana kegiatan mengajukan SPP beserta pendukungnya ke sekretaris desa, kemudian sekretaris desa melakukan verifikasi atas SPP tersebut, Setelah itu SPP di serahkan ke hukum tua untuk disetujui, setelah disetujui oleh hukum tua barulah bendahara desa melakukan pembayaran/pengeluaran uang dari kas desa, dan mencatat transaksi tersebut ke dalam buku kas umum. Oleh karena itu dapat 
disimpulkan bahwa secara pengawasan administrasi dalam proses pengeluaran kas ini masih belum sesuai dengan ketentuan yang ada seperti yang dijelaskan sebelumnya.

3. Asset Tetap

Menurut Penelitian yang dilakukan, Asset Tetap Desa Tincep sudah dikelola sesuai dengan ketentuan umum pengelolaan asset desa (Permendagri No. 1 Tahun 2016), dimana dalam penelitian yang dilakukan didapati bahwa asset desa Tincep selebihnya digunakan untuk kepentingan umum masyarakat yaitu sebagai prasarana olahraga dan fasilitas sosial lainnya. Dan asset desa di inventarisasi dalam buku inventaris asset desa.

4. Pajak

Menurut Penelitian yang dilakukan, Pajak yang dikenakan dalam pengelolaan dana desa ini yaitu jenis Pajak penghasilan dan Pajak pertambahan nilai.

Kemudian menurut penelitian yang dilakukan di Desa Tincep setiap pajak yang dipungut di catatan dalam Buku Pembantu Pajak, dan didapati bahwa Bendahara desa selaku wajib pungut pajak telah melakukan tugas dan tanggungjawab sesuai dengan Permendagri No. 113 Tahun 2014.

\section{KESIMPULAN DAN SARAN}

\subsection{Kesimpulan}

Setelah melakukan penelitian dengan melihat data-data dan keterangan yang diperoleh dari perangkat desa di Desa Tincep Kecamatan Sonder Kabupaten Minahasa yang telah diuraikan dan dibahas pada bagian-bagian sebelumnya, maka dapat diambil kesimpulan bahwa Penerapan Sistem Akuntansi untuk Pengelolaan Dana Desa di Desa Tincep secara pencatatan sudah sesuai dengan Permendagri No. 113/2014 tentang Pengelolaan Keuangan Desa dan PMK Nomor 49/PMK.07/2016 Tentang Tatacara Pengalokasian, Penyaluran, Penggunaan, Pemantauan dan Evaluasi Dana Desa.

Meski demikian masih ada hal yang perlu lebih diperhatikan yaitu di dalam hal pengawasan administrasi terutama dalam proses pengeluaran kas yang masih belum akuntabel dan belum sesuai dengan ketentuan yang semestinya.

\subsection{Saran}

Berdasarkan pembahasan dan kesimpulan yang dikemukakan sebelumnya maka penulis menyarankan :

1. Karena Dana Desa ini di kelola sendiri oleh pemerintah desa maka harus di pergunakan dengan baik dan di pertanggungjawabkan dengan baik khususnya dalam meningkatkan kesejahteraan masyarakat terutama dalam hal pembangunan dan pemberdayaan masyarakat yang tepat sasaran.

2. Setiap proses Akuntansi Penerimaan maupun Pengeluaran kas yang dilakukan harus selalu sesuai dengan prosedur yang semestinya dan berdasarkan undang-undang yang mengatur.

3. Perlu adanya sistem akuntansi yang lebih baik seperti misalnya sistem akuntansi yang terkomputerisasi, agar nantinya pelaporan dana desa akan mampu dilakukan dengan cepat dan output laporan keuangannnya juga akan lebih handal dibanding dengan pelaporan secara manual.

4. Pengelolaan Dana Desa perlu lebih akuntabel dan transparan.

5. Perlu adanya peningkatan kapasitas aparatur desa agar setiap komponen perangkat desa yang ada dapat lebih mengeerti dan memahami akan tugas dan tanggungjawab masingmasing. 


\section{DAFTAR PUSTAKA}

Azhar Susanto, 2013. Sistem Informasi Akuntansi. Bandung : Lingga Jaya

BPKP, 2015. Panduan Pengelolaan Keuangan Desa. Jakarta.

Eko, S. 2014. Desa membangun Indonesia. Yogyakarta: Forum Pengembangan Pembaharuan Desa (FPPD).

Hakim Lukman, Pengelolaan Keuangan Desa/Dana Desa, Kementerian Dalam Negeri Republik Indonesia

Hoesada, J. 2014. Komite standar akuntansi pemerintah (KSAP). Jakarta

Indrawan, R. \& Yaniawati R.P. (2014). Metodologi Penelitian Kuantitatif, Kualitatif, dan Campuran Untuk Manajemen, Pembangunan, dan Pendidikan, Bandung: Penerbit PT Refika Aditama.

Ismail, Muhammad (2016). Sistem Akuntansi Pengelolaan Dana Desa. Skripsi : Fakultas Ekonomi dan Bisnis,Universitas Sebelas Maret

Mulyadi. 2016. Sistem Akuntansi. Jakarta: Salemba Empat.

Peraturan Menteri Dalam Negeri No. 113 tentang Pengelolaan Keuangan Desa

Peraturan Menteri Desa, Pembangunan Daerah Tertinggal, dan Transmigrasi No.22 Tahun 2016 tentang Prioritas Penggunaan Dana Desa TA 2017

Peraturan Pemerintah Desa Tincep Nomor 2 Tahun 2014 tentang RPJM Desa Tincep pada Tahun 2016

Peraturan Pemerintah Nomor 60 Tahun 2014 tentang dana desa yang bersumber dari APBN

Riyani Nunuk. 2016. Analisis Pengelolaan Dana Desa (Studi Kasus Di Desa Singopuran Kecamatan Kartasura Kabupaten Sukoharjo Tahun 2016). Skripsi : Universitas Muhammadiyah Surakarta.

Sujarweni, V Wiratna. 2015. Akuntansi Sektor Publik. Pustaka Baru Press, Yogyakarta.

Undang-undang No. 6 Tahun 2014 Tentang Desa. Jakarta 